University of Nebraska - Lincoln

DigitalCommons@University of Nebraska - Lincoln

\title{
Biodegradation of $17 \beta$-Estradiol, Estrone and Testosterone in Stream Sediments
}

\author{
Paul Bradley \\ Larry Barber \\ Francis Chapelle \\ James Gray \\ Dana Kolpin \\ U.S. Geological Survey \\ See next page for additional authors
}

Follow this and additional works at: https://digitalcommons.unl.edu/usgsstaffpub

Part of the Earth Sciences Commons

Bradley, Paul; Barber, Larry; Chapelle, Francis; Gray, James; Kolpin, Dana; and McMahon, Peter B., "Biodegradation of $17 \beta$-Estradiol, Estrone and Testosterone in Stream Sediments" (2009). USGS Staff -Published Research. 64.

https://digitalcommons.unl.edu/usgsstaffpub/64

This Article is brought to you for free and open access by the US Geological Survey at DigitalCommons@University of Nebraska - Lincoln. It has been accepted for inclusion in USGS Staff -- Published Research by an authorized administrator of DigitalCommons@University of Nebraska - Lincoln. 


\section{Authors}

Paul Bradley, Larry Barber, Francis Chapelle, James Gray, Dana Kolpin, and Peter B. McMahon 
Biodegradation of $17 \beta$-Estradiol, Estrone and Testosterone in Stream Sediments

PAUL M. BRADLEY, ${ }^{*}{ }^{\dagger}$ LARRY B. BARBER, ${ }^{\ddagger}$ FRANCIS H. CHAPELLE, ${ }^{\dagger}$

JAMES L. GRAY, ${ }^{\circledR}$ DANA W. KOLPIN," AND PETER B. MCMAHON ${ }^{\S}$

U.S. Geological Survey, 720 Gracern Rd, Suite 129, Columbia, South Carolina 29210-7651, U.S. Geological Survey, 3215 Marine St, Boulder, Colorado 80303, U.S. Geological Survey, Denver Federal Center, PO Box 25046, Denver, Colorado 80225, and U.S. Geological Survey, 400 S Clinton St, Iowa City, Iowa 5244

Received October 21, 2008. Revised manuscript received January 16, 2009. Accepted January 22, 2009.

Biodegradation of $17 \beta$-estradiol (E2), estrone (E1), and testosterone (T) was investigated in three wastewater treatment plant (WWTP) affected streams in the United States. Relative differences in the mineralization of $\left[4-{ }^{14} \mathrm{C}\right]$ substrates were assessed in oxic microcosms containing saturated sediment or water-only from locations upstream and downstream of the WWTP outfall in each system. Upstream sediment demonstrated significant mineralization of the " $A$ " ring of $E 2, E 1$, and $T$, with biodegradation of $T$ consistently greater than that of $E 2$ and no systematic difference in E2 and E1 biodegradation. " $A$ " ring mineralization also was observed in downstream sediment, with E1 and T mineralization being substantially depressed relative to upstream samples. In marked contrast, E2 mineralization in sediment immediately downstream from the WWTP outfalls was more than double that in upstream sediment. E2 mineralization was observed in water, albeit at insufficient rate to prevent substantial downstream transport. The results indicate that, in combination with sediment sorption processes which effectively scavenge hydrophobic contaminants from the water column and immobilize them in the vicinity of the WWTP outfall, aerobic biodegradation of reproductive hormones can be an environmentally important mechanism for nonconservative (destructive) attenuation of hormonal endocrine disruptors in effluent-affected streams.

\section{Introduction}

The release of endocrine-disrupting chemicals (EDCs) in wastewater treatment plant (WWTP) effluent poses a significant threat to the ecology of surface water receptors due to impacts on the hormonal control, sexual development, reproductive success, and community structure of aquatic organisms and associated wildlife $(1,2)$. The estrogens are of particular concern owing to high endocrine activity (3-6) and additive effects ( 7 ). These hormones have been identified as primary estrogenic agents in wastewater effluent $(8,9)$,

\footnotetext{
* Corresponding author e-mail: pbradley@usgs.gov.

${ }^{\dagger}$ U.S. Geological Survey, Columbia, South Carolina.

${ }^{\ddagger}$ U.S. Geological Survey, Boulder, Colorado.

${ }^{\S}$ U.S. Geological Survey, Denver, Colorado.

" U.S. Geological Survey, Iowa City, Iowa.
}

accounting for greater than $95 \%$ of estrogen receptor agonist activity (10).

E2 and E1 induce vitellogenesis and feminization in fish species $(7,9,11-16)$ at dissolved concentrations as low as 1-10 ng/L (7, 9). WWTP effluent concentrations of 0.1-88 $\mathrm{ng} / \mathrm{L}$ and $0.35-220 \mathrm{ng} / \mathrm{L}$ have been reported for E2 and E1, respectively, with typical detections of $1-10 \mathrm{ng} / \mathrm{L}(8,17-28)$. E2 and E1 in excess of $100 \mathrm{ng} / \mathrm{L}$ have been reported in surface water receptors (29), but are typically in the range of $<0.1-25$ $\mathrm{ng} / \mathrm{L}(17,18,21,22,26-32)$. Because sensitive fish species are affected by concentrations as low as $1 \mathrm{ng} / \mathrm{L}$ and because the effects of reproductive hormone and nonhormonal EDCs are often additive (33), such dissolved concentrations are an environmental concern. Furthermore, estrogen concentrations in surface water sediment can be up to 1000 times higher per volume than in the associated water column, ranging from 0.05 to $29 \mathrm{ng} / \mathrm{g}$ dry weight $(28,34-37)$.

Conservative mechanisms like dilution and sorption have been the foundation of wastewater management in surface water systems, but the fact that reproductive hormones trigger organ- and organism-level responses at ng/L concentrations raises concerns about the ultimate reliability of attenuation mechanisms that do not directly degrade endocrine function (38). Endocrine disruption at hormone concentrations (1-10 ng/L) $(7,9,15,16)$, which have become detectable only with recent analytical innovations, illustrates this concern and emphasizes the importance of characterizing nonconservative, contaminant attenuation processes.

This study assessed the potential for microbial degradation of reproductive hormones in effluent-affected streams. Specific objectives were to assess the ability of stream sediment microorganisms to mineralize reproductive steroid hormones; the relative potential for reproductive hormone biodegradation in stream sediments versus the water column; and the effect of WWTP-effluent on reproductive hormone biodegradation in wastewater affected streams.

\section{Material and Methods}

Chemicals. The potential for in situ biodegradation of effluent-associated reproductive hormones was investigated using aqueous solutions of ${ }^{14} \mathrm{C}$-labeled E2, E1, and T (each $54 \mu \mathrm{Ci} / \mu$ mole; radiochemical purities greater than $97 \%$; American Radiolabeled Chemicals, St. Louis, MO). Substrates were ${ }^{14} \mathrm{C}$-labeled in the $\mathrm{C}-4$ position of the steroid "A" ring (Figure 1); such that recovery of ${ }^{14} \mathrm{CO}_{2}$ indicated ring cleavage and inactivation of the steroid molecule $(39,40) \cdot \mathrm{H}^{14} \mathrm{CO}_{3}{ }^{-}$ (Sigma Biochemicals, St. Louis, MO) and ${ }^{14} \mathrm{CH}_{4}$ (Perkin-Elmer Life Sciences, Boston, MA) were used as standards (radiochemical purities greater than 98\%) for calibration and methods development.

Study Sites. Sediment was collected in June 2006 from three stream systems described previously $(41,42)$ : Fourmile Creek near Ankeny, Iowa (43); Boulder Creek near Boulder, Colorado (44); South Platte River near Denver, Colorado

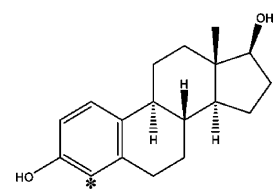

$17 \beta$-Estradiol

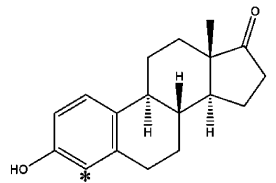

Estrone

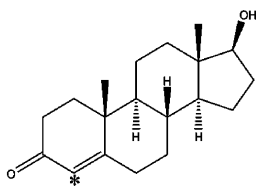

Testosterone
FIGURE 1. Molecular structures of $\left[4-{ }^{14} \mathrm{C}\right] 17 \beta$-estradiol (E2), $\left[4-{ }^{14} \mathrm{C}\right]$ estrone (E1), and $\left[4-{ }^{14} \mathrm{C}\right]$ testosterone (T). Asterisks indicate the location of the ${ }^{14} \mathrm{C}$-radiolabel within the " $\mathrm{A}$ " ring of the steroid backbone. 

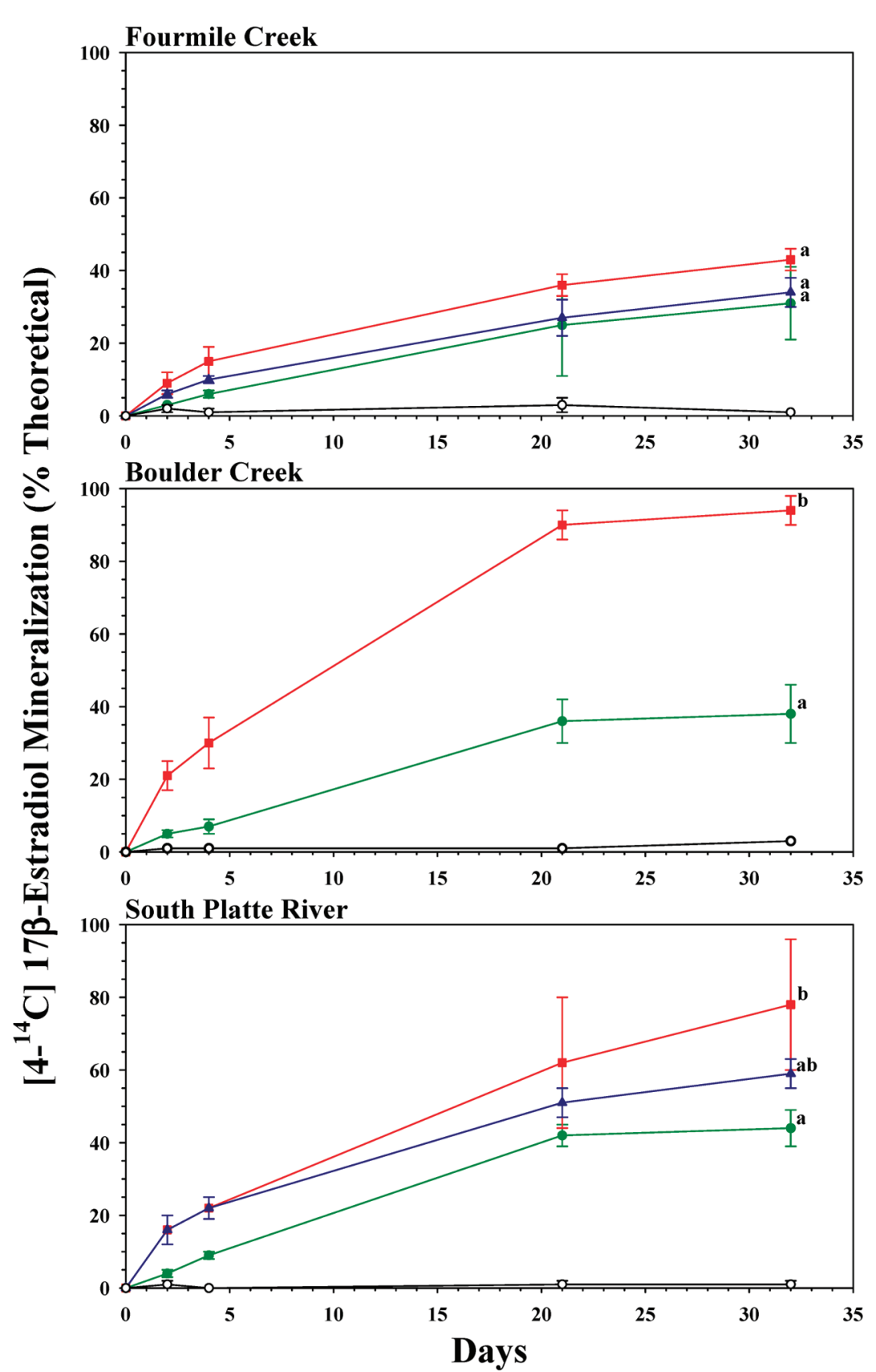

FIGURE 2. Percentage mineralization of $\left[4-{ }^{14} \mathrm{C}\right] 17 \beta$-estradiol (E2) to ${ }^{14} \mathrm{CO}_{2}$ in oxic microcosms containing sediments collected upstream (green, $\bigcirc$ ), immediately downstream (red, $\square$ ), and, when applicable, well downstream (blue, $\Delta$ ) of the wastewater treatment plant (WWTP) outfalls in Fourmile Creek, Ankeny, lowa; Boulder Creek, Boulder, Colorado; and South Platte River, Denver, Colorado. Data are means \pm standard deviations for triplicate experimental microcosms. For each stream, different letters indicate statistically significant differences in the final recovery of ${ }^{14} \mathrm{CO}_{2}$ (one-way ANOVA and Holm-Sidak multiple comparison method; $p<$ 0.05). No significant recovery of ${ }^{14} \mathrm{CO}_{2}$ was observed in autoclaved or sediment-free control microcosms $(O)$.

$(45,46)$. Sediment was collected $30 \mathrm{~m}$ upstream, $30 \mathrm{~m}$ downstream, and $3 \mathrm{~km}$ downstream from the Ankeny WWTP outfall in Fourmile Creek; $200 \mathrm{~m}$ upstream and $20 \mathrm{~m}$ downstream from the Boulder 75th Street WWTP outfall in Boulder Creek; and $100 \mathrm{~m}$ upstream, $100 \mathrm{~m}$ downstream, and $25 \mathrm{~km}$ downstream from the Metro Wastewater Reclamation District (MWRD) outfall on the South Platte River. Each sediment sample, consisting of $250 \mathrm{~mL}$ of surface (top $10 \mathrm{~cm}$ ) material from four points evenly distributed across the stream, was collected in a sterile 1 L glass container. Water samples were collected in a sterile $1 \mathrm{~L}$ glass container from mid-depth at midstream. All samples were collected within a $48 \mathrm{~h}$ period and stored at $4{ }^{\circ} \mathrm{C}$ until microcosm preparation. At the time of sample collection, the effluent contribution to downstream flow in Fourmile Creek was approximately 15\%, while effluent contributions were greater than $50 \%$ and $90 \%$, respectively, in Boulder Creek and the South Platte River.

Dissolved phase concentrations of E1 and E2 were assessed during 2003 and 2005 in the Fourmile Creek and Boulder Creek systems and during 2008 in the South Platte River. Neither contaminant was detected (minimum detection limit $<0.5 \mathrm{ng} / \mathrm{L}$ ) at any location in Fourmile Creek or upstream from the 75th Street WWTP outfall in Boulder Creek. Both hormones were detected downstream in Boulder Creek with an E1 concentration of $110 \mathrm{ng} / \mathrm{L}$ observed at the outfall (2). In the South Platte River, E1 was observed upstream (mean \pm standard deviation; $2.1 \pm 0.1 \mathrm{ng} / \mathrm{L}, n=2$ ) and downstream of the MWRD outfall (22.1 $\pm 0.7 \mathrm{ng} / \mathrm{L}, n=3)$, 


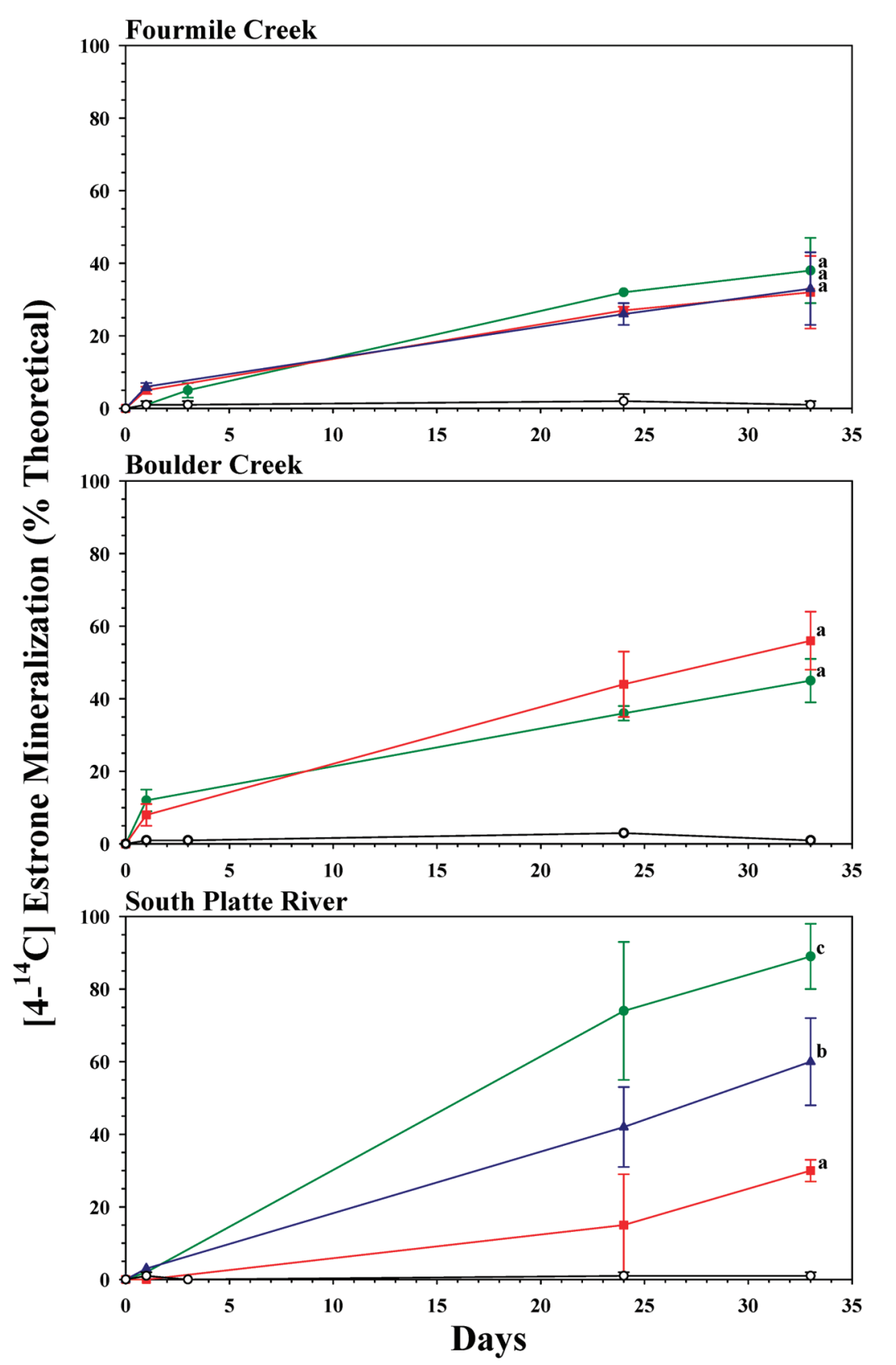

FIGURE 3. Percentage mineralization of $\left[4-{ }^{14} \mathrm{C}\right]$ estrone $(\mathrm{E} 1)$ to ${ }^{14} \mathrm{CO}_{2}$ in oxic microcosms containing sediments collected upstream (green, (), immediately downstream (red, $\square$ ), and, when applicable, well downstream (blue, $\Delta$ ) of the wastewater treatment plant (WWTP) outfalls in Fourmile Creek, Ankeny, lowa; Boulder Creek, Boulder, Colorado; and South Platte River, Denver, Colorado. Data are means \pm standard deviations for triplicate experimental microcosms. For each stream, different letters indicate statistically significant differences in the final recovery of ${ }^{14} \mathrm{CO}_{2}$ (One-way ANOVA and Holm-Sidak multiple comparison method; $p<0.05$ ). No significant recovery of ${ }^{14} \mathrm{CO}_{2}$ was observed in autoclaved or sediment-free control microcosms $(O)$.

whereas E2 was only detected $(8.4 \pm 1.1 \mathrm{ng} / \mathrm{L}, n=3)$ downstream.

Microcosm Studies. Replicate bed sediment microcosms were prepared under oxic conditions as described previously $(41,42,47,48)$ because a recent investigation (42) indicated significant interstitial dissolved oxygen in all three streams. In brief, sediment was thoroughly mixed before dispensing approximately $8 \mathrm{~g}$ saturated material ( $5 \mathrm{~g}$ dry sediment, $3 \mathrm{~mL}$ water) into $11 \mathrm{~mL}$ microcosms. Triplicate experimental, duplicate autoclaved controls and a single sediment free control were prepared for each treatment. All hormone treatments for a given stream and location were prepared from a single, mixed sediment sample. All treatments (stream, location, and hormone) were prepared concurrently (within $48 \mathrm{~h}$ ) approximately 4 weeks after sample collection. Microcosms were amended with $0.04 \mu \mathrm{Ci}$ of $\left[4-{ }^{14} \mathrm{C}\right]$ substrate to yield initial sediment concentrations of $30 \mathrm{ng} / \mathrm{g}$ dry weight, comparable to concentrations reported in effluent-affected stream sediment (34). All sediment microcosms were incubated concurrently in the dark at $23{ }^{\circ} \mathrm{C}$ for $32-34$ days. Microcosms were incubated under static conditions to limit the sediment oxygen supply to diffusion and more readily assess the effects of sediment oxygen demand (42) on hormone mineralization. Water-only ( $5 \mathrm{~mL}$ volume) microcosms were prepared for each stream using $\left[4-{ }^{14} \mathrm{C}\right] \mathrm{E} 2(40$ $\mathrm{ng} / \mathrm{mL}$ initial concentration) as model substrate and incubated in the dark at $23{ }^{\circ} \mathrm{C}$ for 182 days. Headspace concentrations of $\mathrm{CH}_{4},{ }^{14} \mathrm{CH}_{4}, \mathrm{CO}_{2}$, and ${ }^{14} \mathrm{CO}_{2}$ were monitored and oxic conditions (headspace $\left[\mathrm{O}_{2}\right]=2-21 \%$ by volume) were verified by gas chromatography (GC) with thermal conductivity detection (TCD) and radiometric detection (RD) as described in detail $(47,48)$. The headspace sample volume 


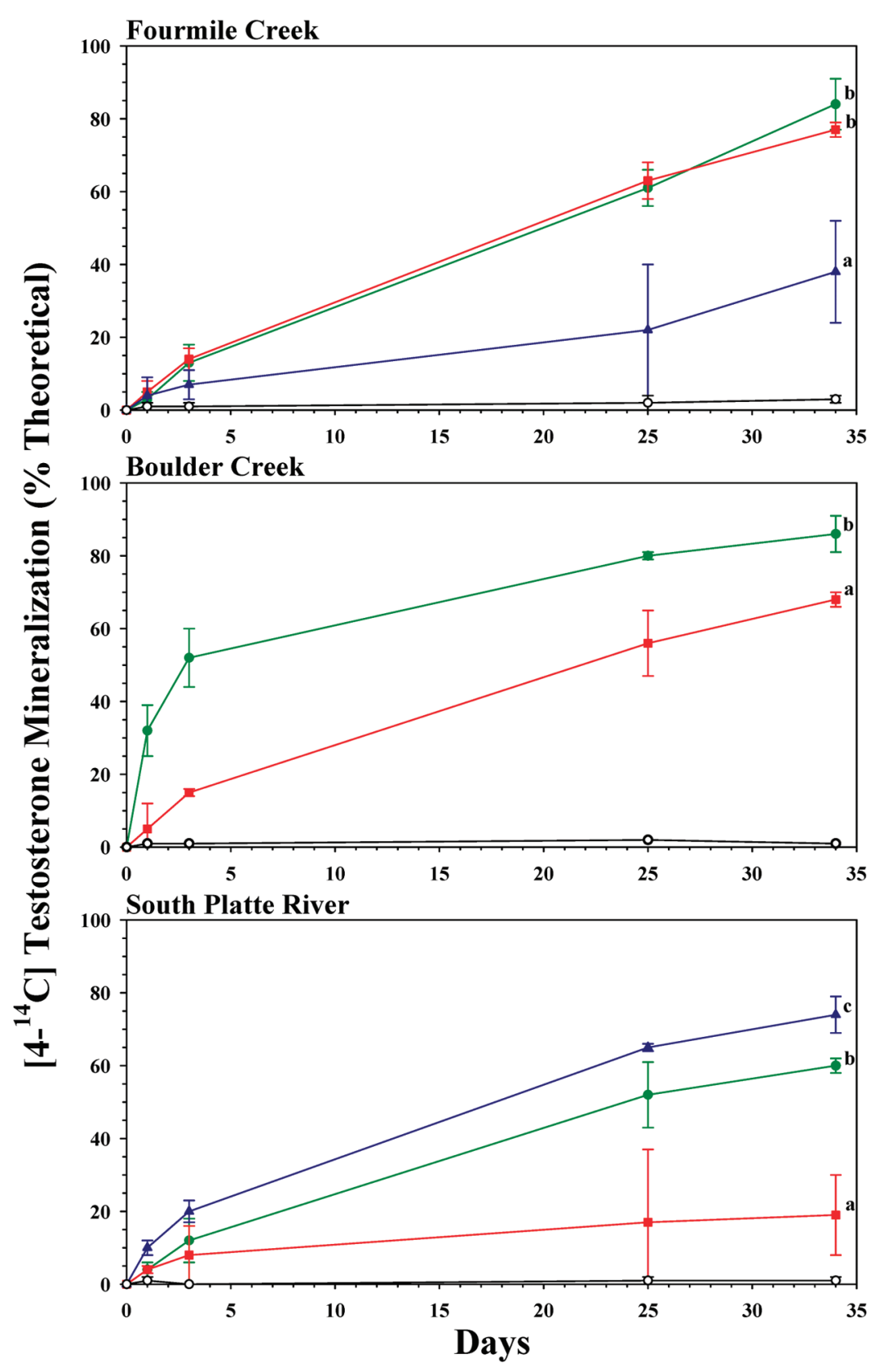

FIGURE 4. Percentage mineralization of $\left[4-{ }^{14} \mathrm{C}\right]$ testosterone $(\mathrm{T})$ to ${ }^{14} \mathrm{CO}_{2}$ in oxic microcosms containing sediments collected upstream (green, 0 ), immediately downstream (red, $\square)$, and, when applicable, well downstream (blue, $\Delta$ ) of the wastewater treatment plant (WWTP) outfalls in Fourmile Creek, Ankeny, lowa; Boulder Creek, Boulder, Colorado; and South Platte River, Denver, Colorado. Data are means \pm standard deviations for triplicate experimental microcosms. For each stream, different letters indicate statistically significant differences in the final recovery of ${ }^{14} \mathrm{CO}_{2}$ (one-way ANOVA and Holm-Sidak multiple comparison method; $p<0.05$ ). No significant recovery of ${ }^{14} \mathrm{CO}_{2}$ was observed in autoclaved or sediment-free control microcosms $(O)$.

was replaced with $100 \%$ oxygen to maintain oxic conditions. GC/RD output was calibrated by liquid scintillation counting using $\mathrm{H}^{14} \mathrm{CO}_{3}{ }^{-}$and sediment biochemical oxygen demand (BOD) was estimated as described (42).

\section{Results and Discussion}

Sediment Upstream from WWTP Outfall. Sediment collected upstream from the WWTP outfall in each of the three surface water systems demonstrated substantial aerobic mineralization of all $\left[4-{ }^{14} \mathrm{C}\right]$ hormone substrates (Figures $2-4$ ), with initial linear rates of ${ }^{14} \mathrm{CO}_{2}$ recovery ranging from approximately $1 \% \mathrm{~d}^{-1}$ (percent of theoretical) for E2 mineralization in Fourmile Creek sediment (Figure 2) up to approximately $30 \% \mathrm{~d}^{-1}$ for T mineralization in Boulder Creek sediment (Figure 4). The recovery of ${ }^{14} \mathrm{CO}_{2}$ observed in this study was attributed to microbial activity because no significant recovery of ${ }^{14} \mathrm{CO}_{2}$ (recovery less than $2 \%$ of theoretical) was observed in sterilized control microcosms. Recovery of ${ }^{14} \mathrm{CO}_{2}$ was interpreted as explicit evidence of microbial cleavage of the steroid "A" ring and loss of endocrine activity, as demonstrated previously using the yeast estrogen screen (YES) assay $(39,40)$. The results are consistent with previous reports of microbial transformation and "A" ring cleavage of $\left[4-{ }^{14} \mathrm{C}\right]$ E2 in rivers in the United Kingdom (40) and Japan (49) and suggest that the potential for aerobic biodegradation of reproductive hormones may be widespread in stream systems.

Upstream sediments were not under the immediate influence of wastewater discharge and served as "background" samples. Anthropogenic effects cannot be dismissed 


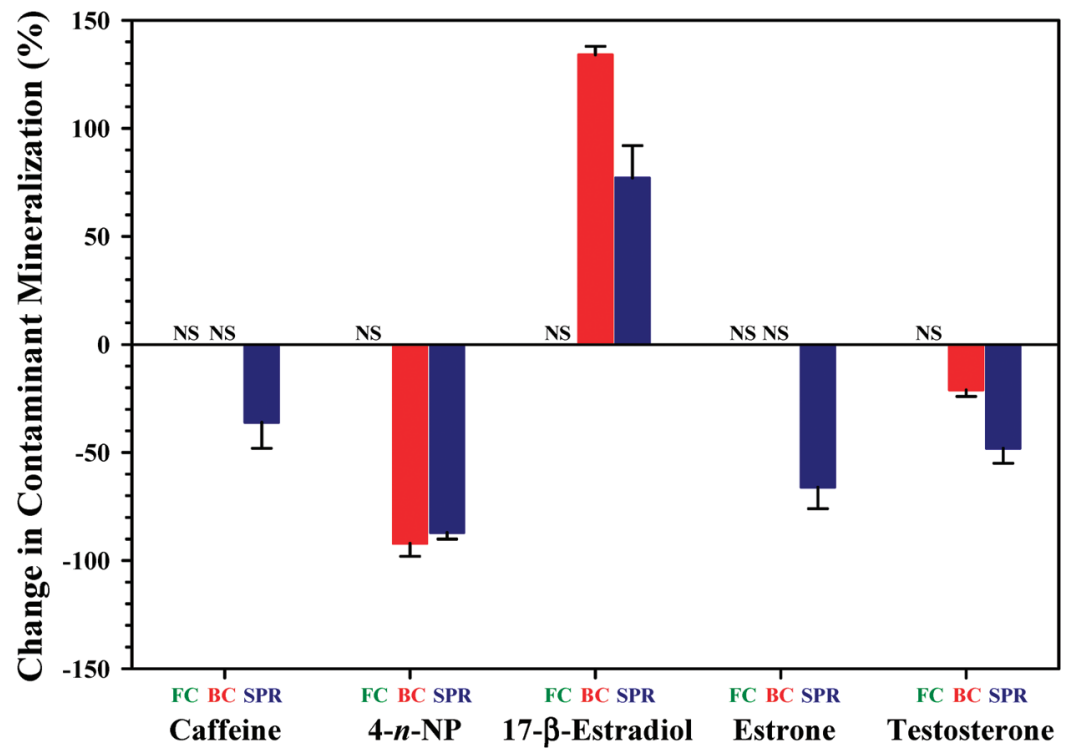

FIGURE 5. Relative change in the extent of aerobic mineralization of [8-ring- ${ }^{14} \mathrm{C}$ ] caffeine (Bradley et al., 2007), [U-ring- ${ }^{14} \mathrm{C}$ ] 4-n-nonylphenol (4-n-NP)(Bradley et al., 2008), $\left[4-{ }^{14} \mathrm{C}\right] 17 \beta$-estradiol (E2), $\left[4-{ }^{14} \mathrm{C}\right]$ estrone (E1), and $\left[4-{ }^{14} \mathrm{C}\right]$ testosterone $(\mathrm{T})$ to ${ }^{14} \mathrm{CO}{ }_{2}$ between sediment collected upstream and immediately downstream from the WWTP outfalls in Fourmile Creek (FC), Boulder Creek (BC), and South Platte River (SPR). Bars in the positive range indicate a net increase in contaminant mineralization between upstream and downstream locations. Bars in negative range indicate a net decrease. Data are means \pm standard deviations for triplicate experimental microcosms after 34 days of incubation. NS (not significant) indicates that upstream and downstream locations did not differ significantly (One-way ANOVA; $p<0.05$ ).

at upstream locations, however, because all three reaches were in urban areas. In particular, the South Platte MWRD reach was $19 \mathrm{~km}$ downstream from a preceding outfall. In the absence of an immediate source of contamination and in light of their structural similarity (Figure 1), little variation in biodegradation potential between individual compounds was expected in these "background" sediments. Nevertheless, $\mathrm{T}$ was generally more biodegradable than either E2 or E1 within individual stream systems.

Sediment Downstream from WWTP Outfall. Effluent may enhance in situ biodegradation of hormone contaminants by introducing WWTP-derived degradative populations or by stimulating the indigenous microorganisms through increased supply of nutrients and cometabolites. Alternatively, toxins (biocides, antibiotics, toxic metals, etc) in the waste stream, competitive inhibition by effluent-derived carbon substrates, and depletion of efficient terminal electron acceptors like oxygen may depress biodegradation.

Previous investigations conducted in these three stream systems on the potential for biodegradation of wastewater indicators compounds (caffeine, cotinine, nicotine) and the endocrine-disrupting detergent metabolite, 4-nonylphenol (4-NP), reported consistent inhibition of microbial degradation downstream from the respective WWTP $(47,48)$. In this study, however, the effect of WWTP effluent on the biodegradation of reproductive hormones varied between stream systems and target hormones. Due, perhaps, to the low contribution of effluent to downstream flow (about 15\% of downstream flow at the time of sample collection) and/or the lack of detectable concentrations of reproductive hormones, little difference in hormone mineralization was observed between sediment collected upstream, immediately downstream, or $3 \mathrm{~km}$ downstream from the WWTP outfall in Fourmile Creek (Figures 2-4). In the more effluentdominated Boulder Creek and South Platte River reaches, however, biodegradation of reproductive hormones often differed between upstream and downstream sediment locations (Figures 2-4). Mineralization of the "A" ring of E1 and $\mathrm{T}$, generally declined in sediment collected immediately downstream from the WWTP outfall in Boulder Creek and the South Platte River. The fact that "A" ring mineralization of E1 and T in sediment collected approximately $10 \mathrm{~km}$ downstream from the MWRD outfall on the South Platte River was comparable to that observed upstream from the outfall, suggests that the inhibitory impact of WWTP effluent on biodegradation was localized.

In contrast, E2 “A” ring mineralization was substantially greater in sediment collected immediately downstream from the WWTP outfall in the effluent-dominated Boulder Creek and South Platte River study reaches (Figure 2). The recovery of ${ }^{14} \mathrm{CO}_{2}$ in the immediate downstream sediment was approximately twice that observed upstream of the outfall in Boulder Creek and the South Platte River (Figure 2). A comparison of the relative change in ring cleavage and subsequent mineralization of diverse wastewater contaminants between upstream and outfall sediments (Figure 5) emphasizes the atypical response of sediment E2 mineralization to effluent exposure. Of the five wastewater contaminants, only E2 mineralization was stimulated in sediment collected immediately downstream from the WWTP outfall in the effluent-dominated Boulder Creek and South Platte River reaches (Figure 5). The fact that no difference in E2 "A" ring mineralization was observed between upstream and downstream locations in the less effluent-affected Fourmile Creek suggested that the stimulation of E2 mineralization observed in the Boulder Creek and South Platte River study reaches was attributable to some characteristic of the WWTP effluent and may be concentration dependent.

The different responses of E2 and E1 "A" ring mineralization to effluent exposure is striking, considering their structural similarity and that E1 is often suggested as an intermediate in E2 biodegradation $(27,39,40)$. Final ${ }^{14} \mathrm{CO}_{2}$ recoveries from $\left[4-{ }^{14} \mathrm{C}\right] \mathrm{E} 2$ were $65 \%$ and $150 \%$ greater than from $\left[4-{ }^{14} \mathrm{C}\right] \mathrm{E} 1$ in Boulder Creek and the South Platte River, respectively (Figures 2 and 3). Thus, the outfall sediment microbial communities in both reaches demonstrated increased degradation and marked substrate specificity for E2. This observation indicates that E2 mineralization in downstream sediments in Boulder Creek and the South Platte River did not involve initial conversion to $\mathrm{E} 1$, as has been reported for aerated activated sludge systems (27). 


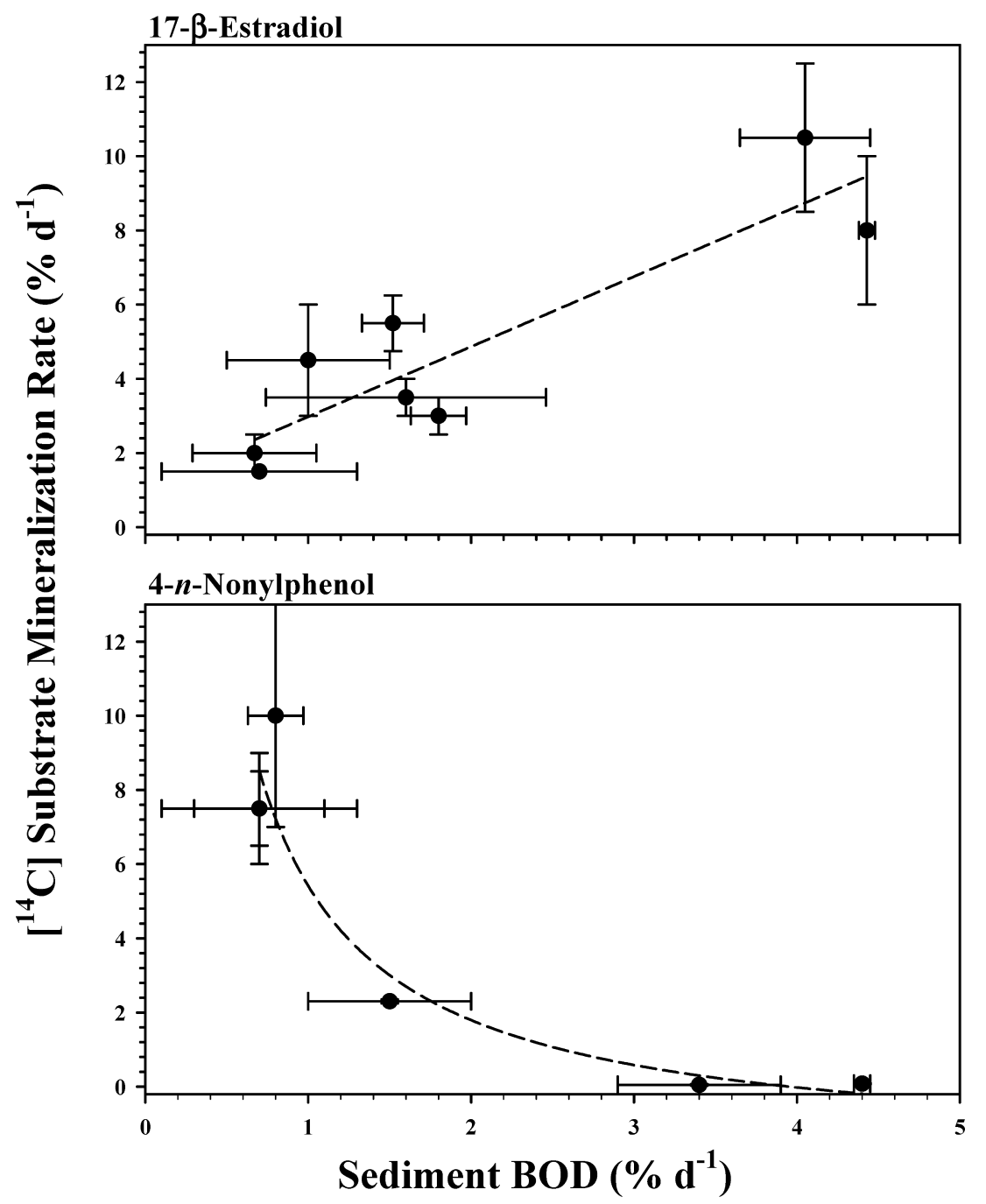

FIGURE 6. Relation between the initial linear rate of mineralization of $\left[4-{ }^{14} \mathrm{C}\right] 17 \beta$-estradiol (E2) or $\left[\mathrm{U}\right.$-ring- $\left.{ }^{14} \mathrm{C}\right] 4-n$-nonylphenol (4-n-NP) to ${ }^{14} \mathrm{CO}_{2}\left(\% \mathrm{~d}^{-1}\right)$ and the sediment biological oxygen demand (BOD in \% $\left.\mathrm{d}^{-1}\right)$ for sediments collected from all locations in Fourmile Creek, Boulder Creek, and S. Platte River. Data are means \pm standard deviations for quadruplicate experimental microcosms.

Sediment BOD and Biodegradation. In two previous studies in these reaches, the inhibitory effect of WWTP effluent on downstream biodegradation of diverse wastewater contaminants (cotinine, nicotine, caffeine, and 4-NP) was attributed, in part, to effluent-associated increases in BOD and a concomitant shift toward less efficient anoxic biodegradation $(47,48)$. Thus, the relation between sediment BOD and "A" ring mineralization of $\mathrm{E} 2, \mathrm{E} 1$, and $\mathrm{T}$ was also assessed in this study. The static conditions, under which all treatments were incubated, effectively limited oxygen supply to diffusion and exaggerated the impact of sediment BOD on oxygen availability. The relation between sediment hormone mineralization and sediment BOD was assessed by comparing the initial linear rate of $\left[4-{ }^{14} \mathrm{C}\right]$ hormone mineralization with the sediment BOD for all locations in the three study reaches.

No significant correlations between BOD and mineralization of $\left[4-{ }^{14} \mathrm{C}\right] \mathrm{E} 1$ or $\left[4-{ }^{14} \mathrm{C}\right] \mathrm{T}$ were observed (Spearman Rank Order Correlation $p=0.39$ and $p=0.79$ for $\mathrm{E} 1$ and $\mathrm{T}$, respectively). Mineralization of $\left[4-{ }^{14} \mathrm{C}\right]$ E2 increased significantly (Spearman Rank Order Correlation; $p=0.029$ ); $r^{2}=$ 0.80 for simple linear regression of E2 mineralization against BOD) with sediment BOD in this study (Figure 6).

The positive correlation between E2 mineralization and sediment BOD (Figure 6) contrasts with the negative relation between sediment BOD and 4-NP mineralization in these reaches (42). Because mineralization of [U-ring- $\left.{ }^{14} \mathrm{C}\right] 4-n$-NP to ${ }^{14} \mathrm{CO}_{2}$ was completely inhibited under anoxic conditions, the negative correlation between 4-NP mineralization and sediment BOD was attributed to oxygen limitation (42). While the impact of anoxia on E2 mineralization was not assessed here, previous investigations reported only biotransformation of E2 to E1 and no detectable "A" ring mineralization under anoxic conditions $(27,31,39,40,50)$. Thus, the positive correlation between E2 mineralization and sediment BOD in this study was attributed to effluent-associated factors that promote $\mathrm{E} 2$ biodegradation despite BOD-driven oxygen limitations. Inoculation of the downstream sediment with WWTP-derived microorganisms capable of efficient E2 degradation appears likely $(27,31,39,40,51)$.

E2 Biodegradation in Sediment and Water. The experimental approach focused on sediment biodegradation, because the hydrophobic character of reproductive hormones favors sorption and results in sediment concentrations up to 1000 times higher on a per volume basis than in the associated water column (28,34-37). In light of the frequent detection of reproductive hormones in the aqueous phase of effluent-affected streams, however, a limited assessment of the potential for biodegradation of hormone contaminants within the water column was conducted using $\left[4-{ }^{14} \mathrm{C}\right] \mathrm{E} 2$ as a model substrate.

Mineralization of $\left[4-{ }^{14} \mathrm{C}\right] \mathrm{E} 2$ to ${ }^{14} \mathrm{CO}_{2}$ was observed in wateronly microcosms in this study, but the extent of biodegradation 


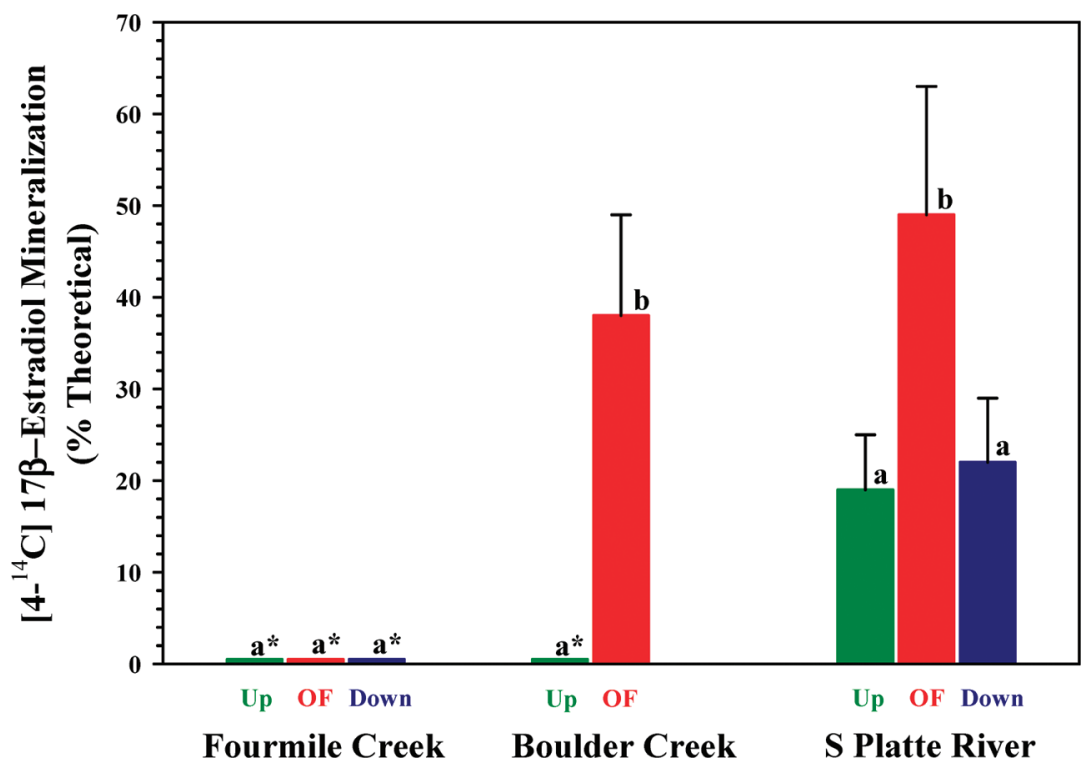

FIGURE 7. Final percentage mineralization of $\left[4-{ }^{14} \mathrm{C}\right] 17 \beta$-estradiol (E2) to ${ }^{14} \mathrm{CO}_{2}$ in oxic microcosms containing only water collected upstream (Up), immediately downstream (OF), and, when applicable, well downstream (Down) of the wastewater treatment plant (WWTP) outfalls in Fourmile Creek, Boulder Creek, and South Platte River after 182 days. Data are means \pm standard deviations for triplicate experimental microcosms. For each stream, different letters indicate statistically significant differences between treatments (One-way ANOVA and Holm-Sidak multiple comparison method; $p<0.05$ ). Asterisks indicate no significant recovery of ${ }^{14} \mathrm{CO}_{2}$ was observed. No significant recovery of ${ }^{14} \mathrm{CO}_{2}$ was observed in autoclaved or sediment-free control microcosms.

varied considerably between systems (Figure 7). At Fourmile Creek, no evidence of E2 "A" ring mineralization was observed. The lack of biodegradation in Fourmile Creek water may reflect a lack of selective pressure, as E2 was not detected in the water column and effluent, a potential source of E2 degrading microorganisms, contributed only about $15 \%$ of the downstream flow in Fourmile Creek at the time of sample collection. In contrast, significant mineralization of $\left[4-{ }^{14} \mathrm{C}\right] \mathrm{E} 2$ was observed in Boulder Creek and South Platte River water microcosms (Figure 7). The final recovery of ${ }^{14} \mathrm{CO}_{2}$ in water collected immediately downstream from the WWTP outfall was at least twice that observed in upstream water (Figure 7). This pattern is similar to that for E2 mineralization in corresponding sediment microcosms and consistent with the hypothesis that some component of the WWTP effluent enhanced E2 biodegradation in these locations.

The rate of E2 mineralization observed in water-only microcosms was at least an order of magnitude lower than that in treatments prepared with an equivalent volume of stream-bed sediment (Figure 7). Significant E2 mineralization was observed in Fourmile Creek sediment but not in wateronly microcosms. No E2 mineralization was apparent in Boulder Creek or South Platte River water-only treatments after 2, 4, or 10 day incubations (data not shown). Final recoveries of ${ }^{14} \mathrm{CO}_{2}$ in water-only Boulder Creek and South Platte River treatments after 182 days of incubation were generally less than half of that observed in corresponding sediment treatments after only 32 days. Maximum rates of E2 mineralization (averaged over 182 days) in Boulder Creek and South Platte River water-only treatments were on the order of $0.001 \mathrm{~d}^{-1}$, whereas downstream velocities in these systems were on the order of $\mathrm{km} \mathrm{d}^{-1}$. Thus, while E2 mineralization may be appreciable in the water columns of some systems, it may not be a significant attenuation mechanism for endocrine activity in all surface waters and does not appear to be sufficient to prevent substantial downstream transport

Implications for WWTP-Affected Stream Systems. The rates of aerobic reproductive hormone mineralization observed in this study in water-only treatments were low relative to streamflow velocities. Consequently, acting alone, biodegradation in the water column appears unlikely to prevent substantial downstream transport. However, the hydrophobic character of reproductive hormones results in partitioning to the sediment phase $(31,34)$ where the potential for aerobic microbial mineralization of reproductive hormones appears substantial. Thus, in combination with sediment sorption processes which effectively scavenge hydrophobic contaminants from the water column and immobilize them in the vicinity of the WWTP outfall, aerobic biodegradation of reproductive hormones can be an environmentally important mechanism for nonconservative (i.e., destructive) attenuation of the endocrine disrupting activity of these potent environmental contaminants in effluent-affected streams. Moreover, the aerobic mineralization observed in this investigation indicates that the assimilative capacity approach, the historical cornerstone of WWTP effluent management, also may be feasible for reproductive hormone contaminants, once environmentally protective water-quality criteria have been established.

\section{Acknowledgments}

This research was supported by the U.S. Geological Survey Toxic Substances Hydrology Program. Disclaimer: The use of trade, product, or firm names in this paper is for descriptive purposes only and does not imply endorsement by the U.S. Government.

\section{Literature Cited}

(1) Lintelmann, J.; Katyama, A.; Kurihara, N.; Shore, L.; Wenzel, A. Endocrine disrupters in the environment. Pure Appl. Chem. 2003, 75 (5), 631-681.

(2) Vajda, A. M.; Barber, L. B.; Gray, J. L.; Lopez, E. M.; Woodling, J. D.; Norris, D. O. Reproductive disruption in fish downstream from and estrogenic wastewater effluent. Environ. Sci. Technol. 2008, 42 (9), 3407-3414.

(3) Islinger, M.; Pawlowski, S.; Hollert, H.; Volki, A.; Braumbeck, T. Measurement of vitellogenin-mRNA expression in primary cultures of rainbow trout hepatocytes in a non-radioactive dot blot/RNAse protection-assay. Sci. Total Environ. 1999, 233 (13), 109-122.

(4) Kidd, K. A.; Blanchfield, P. J.; Mills, K. H.; Palace, V. P.; Evans, R. E.; Lazorchak, J. M.; Flick, R. W. Collapse of a fish population after exposure to a synthetic estrogen. Proc. Natl. Acad. Sci.U. S. A. 2007, 104 (21), 8897-8901. 
(5) Shelby, M. D.; Newbold, R. R.; Tully, D. B.; Chae, K.; Davis, V. L. Assessing environmental chemicals for estrogenicity using a combination of in vitro and in vivo assays. Environ. Health Perspect. 1996, 104 (12), 1296-1300.

(6) Soto, A. M.; Sonnenschein, C.; Chung, K. L.; Fenandez, M. F.; Olea, N.; Serrano, F. O. The E-SCREEN assay as a tool to identify estrogens: an update on estrogenic environmental pollutants. Environ. Health Perspect. 1995, 103 (7), 113-122.

(7) Thorpe, K. L.; Hutchinson, T. H.; Hetheridge, M. J.; Scholze, M.; Sumpter, J. P. Assessing the biological potency of binary mixtures of environmental estrogens using vitellogenin induction in juvenile rainbow trout (Oncorhyncus mykiss). Environ. Sci. Technol. 2001, 35 (12), 2476-2481.

(8) Desbrow, C.; Routledge, E. J.; Brighty, G. C.; Sumpter, J. P.; Waldock, M. Identification of estrogenic chemicals in STW effluent. 1. Chemicals fractionation and in vitro biological screening. Environ. Sci. Technol. 1998, 32 (11), 1549-1558.

(9) Routeledge, E. J.; Sheahan, D.; Desbrow, C.; Brighty, G. C.; Waldock, M.; Sumpter, J. P. Identification of estrogenic chemicals in STW effluent. 2. In vivo responses in trout and roach. Environ. Sci. Technol. 1998, 32 (11), 1559-1565.

(10) Snyder, S. A.; Villeneuve, D. L.; Snyder, E. M.; Giesy, J. P. Identification and quantification of estrogen receptor agonists in wastewater effluents. Environ. Sci. Technol. 2001, 35 (18), 3620-3625.

(11) Allner, B.; Wegener, G.; Knacker, T.; Stahlschmidt-Allner, P. Electrophoretic determination of estrogen-protein in fish exposed to synthetic and naturally occurring chemicals. Sci. Total Environ. 1999, 233, 21-31.

(12) Folmar, L. C.; Hemmer, M.; Hemmer, R.; Bowman, C.; Kroll, K.; Denslow, N. D. Comparative estrogenicity of estradiol, ethynyl estradiol and diethylstilbestrol in an in vivo male sheepshead minnow (Cypinodon variegatus) vitellogenin bioassay. Aquat. Toxicol. 2000, 49 (1-2), 77-88.

(13) Jobling, S.; Nolan, M.; Tyler, C. R.; Brighty, G.; Sumpter, J. P. Widespread sexual disruption in wild fish. Environ. Sci. Technol. 1998, 32 (17), 2498-2506.

(14) Kramer, K. J.; Miles-Richarson, S.; Pieren, S. L.; Giesy, J. P. Reproductive impairment and induction of alkaline-labile phosphate, a biomarker of estrogen exposure, in fathead minnows (Pimephales promelas) exposed to waterborne $17 \beta$ estradiol. Aquat. Toxicol. 1998, 40 (4), 335-360.

(15) Nimrod, A. C.; Benson, W. H. Reproduction and development of Japanes medaka following an early life stage exposure to xenoestrogens. Aquat. Toxicol. 1998, 44 (1-2), 141-156.

(16) Thorpe, K. L.; Hutchinson, T. H.; Hetheridge, M. J.; Sumpter, J. P.; Tyler, C. R. Development of an in vivo screening assay for estrogenic chemicals using juvenile rainbow trout (Oncohychus mykiss). Environ. Toxicol. Chem. 2000, 19 (11), 28122820.

(17) Baronti, C.; Curini, R.; D’Ascenzo, G.; Di Corcia, A.; Gentili, A.; Samperi, R. Monitoring natural and synthetic estrogens at activated sludge sewage treatment plants and in receiving river water. Environ. Sci. Technol. 2000, 34 (24), 5059-5066.

(18) Belfroid, A.; Van der Horst, A.; Vethaak, A. D.; Schafer, A. J.; Rijs, G. B. J.; Wegener, J.; Cofino, W. P. Analysis and occurrence of estrogenic hormones and their glucuronides in surface water and waste water in The Netherlands. Sci. Total Environ. 1999, $225(1-2), 101-108$.

(19) Hansen, P. D.; Dizer, H.; Hock, B.; Marx, A.; Sherry, J.; McMaster, M.; Blaise, C. Vitellogenin - a biomarker for endocrine disruptors. Trends Anal. Chem. 1998, 17 (7), 448-451.

(20) Johnson, A. C.; Belfroid, A.; Di Corcia, A. Estimating steroid oestrogen inputs into activated sludge treatment works and observations on their removal from the effluent. Sci. Total Environ. 2000, 256 (2-3), 163-173.

(21) Kanda, R.; James, H.; Harding, L.; Franklin, O. Analysis of Water, Treated Sewage Effluent and River Bed Sediment Samples for Steroid Oestrogens, Report for Natural Environment Research Council. WRc-NSF No. 12301-0; Natural Environment Research Council: Swindon, UK, 2001.

(22) Kuch, H. M.; Ballschmiter, K. Determination of endocrinedisrupting phenolic compounds and estrogens in surface and drinking water by HRGC-(NCI)-MS in the pictogram per liter range. Environ. Sci. Technol. 2001, 35 (15), 3201-3206.

(23) Niven, S. J.; Hetheridge, M.; Evans, M.; McEvoy, J.; Sutton, P. G.; Rowland, S. J. Investigations of the origins of estrogenic A-ring aromatic steroids in UK sewage treatment works effluents. Analyst. 2001, 126 (3), 285-287.

(24) Rodgers-Gray, T. P.; Jobling, S.; Morris, S.; Kelly, C.; Kirby, S.; Janbakhsh, A.; Harries, J. E.; Waldock, M. J.; Sumpter, J. P.; Tyler,
C. R. Long-term temporal changes in the estrogenic composition of treated sewage effluent and its biological effects on Fish. Environ. Sci. Technol. 2000, 34 (8), 1521-1528.

(25) Stumpf, M.; Ternes, T. A.; Haberer, K.; Baumann, W. Determination of natural and synthetic estrogens in sewage plants and river water. Vom Wasser. 1996, 87, 251-261.

(26) Ternes, T. A.; Stumpf, M.; Mueller, J.; Wilken, R-D.; Haberer, K.; Servos, M. Behavior and occurrence of estrogens in municipal sewage treatment plants, I: Investigations in Germany, Canada and Brazil. Sci. Total Environ. 1999, 225 (1-2), 81-90.

(27) Ternes, T. A.; Kreckel, P.; Mueller, J. Behavior and occurrence of estrogens in municipal sewage treatment plants, II: Aerobic batch experiments with activated sludge. Sci. Total Environ. 1999, 225 (1-2), 91-99.

(28) Williams, R. J.; Johnson, A. C.; Smith, J. J. L.; Kanda, K. Steroid estrogens profiles along river stretches arising from sewage treatment works discharge. Environ. Sci. Technol. 2003, 37 (9), 1744-1750.

(29) Kolpin, D. W.; Furlong, E. T.; Meyer, M. T.; Thurman, E. M.; Zaugg, S. D.; Barber, L. B.; Buxton, H. T. Pharmaceuticals, hormones and other organic wastewater contaminants in U.S. streams, 1999-2000: A national synthesis. Environ. Sci. Technol. 2002, 36 (6), 1202-1211.

(30) Campbell, C. G.; Borglin, S. E.; Bailey, G. F.; Grayson, A.; Wozei, E.; Stringfellow, W. T. Biologically directed environmental monitoring, fate, and transport of estrogenic endocrine disrupting compounds in water: A review. Chemosphere. 2006, 65 (8), 1265-1280.

(31) Ying, G-G.; Kookana, R. S.; Ru, Y-J. Occurrence and fate of hormone steroids in the environment. Environ. Int. 2002, 28 (6), 545-551.

(32) Fawell, J. K.; Sheahan, D.; James, H. A.; Hurst, M.; Scott, S. Oestrogens and oestrogenic activity in raw and treated water in Severn Trent water. Water Res. 2001, 35 (5), 1240-1244.

(33) Thorpe, K. L.; Gross-Sorokin, M.; Johnson, I.; Brighty, G.; Taylor, C. R. An assessment of the model of concentration addition for predicting the estrogenicity of chemical mixtures from wastewater treatment works effluents. Environ. Health Perspect. 2006, 114 (S-1), 90-97.

(34) Labadie, P.; Cundy, A. B.; Stone, K.; Andrews, M.; Valbonesi, S.; Hill, E. M. Evidence for the migration of steroidal estrogens through river bed sediments. Environ. Sci. Technol. 2007, 41 (12), 4299-4304.

(35) Liu, R.; Zhou, J. L.; Wilding, A. Microwave assisted extraction followed by gas chromatography-mass spectrometry for the determination of endocrine disrupting chemicals in river sediment. J. Chromatogr., A 2004, 1038 (1-2), 19-26.

(36) Peck, M.; Gibson, R. W.; Kortenkamp, A.; Hill, E. M. Sediments are major sinks of steroidal estrogens in two United Kingdom rivers. Environ. Toxicol. Chem. 2004, 23 (4), 945-952.

(37) Petrovic, M.; Sole, M.; Lopez De Alda, M. J.; Barcelo, D. Endocrine disruptors in sewage treatment plants, receiving river waters and sediments: Integration of chemical analysis and biological effects on feral carp. Environ. Toxicol. Chem. 2002, 21 (10), 21462156.

(38) Holz, S. There Is No "Away" Pharmaceuticals, Personal Care Products, And Endocrine-Disrupting Substances: Emerging Contaminants Detected in Water; Canadian Institute for Environmental Law and Policy: Toronto, Ontario, Canada, 2006; pp 82, Available at http://www.cielap.org/pdf/NoAway.pdf.

(39) Layton, A. C.; Gregory, B. W.; Seward, J. R.; Schultz, T. W.; Sayler, G. S. Mineralization of steroidal hormones by biosolids in wastewater treatment systems in Tennessee U.S.A. Environ. Sci. Technol. 2000, 34 (18), 3925-3931.

(40) Jürgens, M. D.; Holthaus, K. I. E.; Johnson, A. C.; Smith, J. J. L.; Hetheridge, M.; Williams, R. J. The potential for estradiol and ethinylestradiol degradation in English rivers. Environ. Toxicol. Chem. 2002, 21 (3), 480-488.

(41) Bradley, P. M.; Barber, L. B.; Kolpin, D. W.; McMahon, P. B.; Chapelle, F. H. Biotransformation of caffeine, cotinine, and nicotine in stream sediments: Implications for use as wastewater indicators. Environ. Toxicol. Chem. 2007, 26 (6), 1116-1121.

(42) Bradley, P. M.; Barber, L. B.; Kolpin, D. W.; McMahon, P. B.; Chapelle, F. H. Potential for 4- $n$-nonylphenol biodegradation in stream sediments. Environ. Toxicol. Chem. 2008, 27 (2), 260265.

(43) Schnoebelen, D. J.; Kolpin, D. W.; Barber, L. B.; Furlong, E. T.; Meyer, M. M.; Skopec, M. Research plan and preliminary results: A field research site for emerging contaminants in Iowa. J. Iowa Acad. Sci. 2006, 113 (1-2)), 1-9. 
(44) Barber, L. B.; Murphy, S. F.; Verplank, P. L.; Sandstrom, M. W.; Taylor, H. E.; Furlong, E. T. Chemical loading into surface water along a hydrological, biogeochemical, and land use gradient: A holistic watershed approach. Environ. Sci. Technol. 2006, 40 (2), 475-486.

(45) McMahon, P. B.; Tindall, J. A.; Collins, J. A.; Lull, K. J.; Nuttle, J. R. Hydrologic and geochemical effects on oxygen uptake in bottom sediments of an effluent-dominated river. Water Resour. Res. 1995, 31 (10), 2561-2569.

(46) McMahon, P. B.; Lull, K. J.; Dennehy, K. F.; Collins, J. A. Quantity and Quality of Groundwater Discharge to the South Platte River, Denver to Fort Lupton, Colorado, August 1992 through July 1993, U.S. Geological Survey Water-Resources Investigation Report 95-4110; U.S. Geological Survey: Reston, VA, 1995.

(47) Bradley, P. M.; Chapelle, F. H.; Landmeyer, J. E. Effect of redox conditions on MTBE biodegradation in surface water sediments. Environ. Sci. Technol. 2001, 35 (23), 4643 4647.

(48) Bradley, P. M.; Landmeyer, J. E.; Chapelle, F. H. TBA biodegradation in surface-water sediments under aerobic and anaerobic conditions. Environ. Sci. Technol. 2002, 36 (19), 4087-4090.

(49) Matsuoka, S.; Kikuchi, M.; Kimura, S.; Kurokawa, Y.; Kawai, S. Determination of estrogenic substances in the water of Muko River using in vitro assays, and the degradation of natural estrogens by aquatic bacteria. J. Health Sci. 2005, 51 (2), 178184.

(50) Czajka, C. P.; Londry, K. L. Anaerobic biotransformation of estrogens. Sci. Total Environ. 2006, 367 (2-3), 932-941.

(51) Johnson, A. C.; Sumpter, J. P. Removal of endocrine-disrupting chemicals in activated sludge treatment works. Environ. Sci. Technol. 2001, 35 (24), 4697-4703.

ES802797J 